\title{
A milícia e o processo de individuação: entre a falta e a falha do Estado
}

Greciely Cristina da Costa (UNIVÁS)

\section{Resumo}

Neste artigo, refletimos sobre o modo como a falta e a falha do Estado intervêm no processo de individuação ressaltando que a individuação do sujeito pelo Estado, de acordo com Orlandi (2012), éuma questão política dada a relação do indivíduo com a sociedade. Para isso, observamos a configuração da milícia face ao espaço da favela e em relação ao Estado. Ao mesmo tempo, procuramos explicitar algumas discursividades que enunciam a forma pela qual a milícia é identificada em discursos sobre ela, notadamente em uma en trevista realizada com moradores do Rio de Janeiro.

Palavras-chave: Discurso; Milícia; Processo de Individuação. 
1 Agradeço ao Prof. Dr. Ignacio Cano pela concessão de parte de seu material de pesquisa, cuja entrevista com moradores do Rio de Janeiro, alguns de áreas miliciadas, foi coletada pela equipe de pesquisadores do LAV (Laboratório de Análise da Violência), da Universidade Estadual do Rio de Janeiro (UERJ). $\mathrm{Na}$ entrevista os sujeitos eram questionados sobre a milícia e sua atuação.

2 Fazem parte da milícia, além dos policiais e ex-policiais, bombeiros e agentes penitenciários, mas esses são minoria, por isso, preferimos destacar o nome polícia, pois é ele, também, que é enunciado para se referir à milícia.
A gente quase nunca vê. Esse pessoal do exterminio a gente quase nunca vê. Teve até um desses do exterminio, que ele andou preso; ele é policial, porque teve um inquérito, descobriram que ele estava exterminando. Mas ele não foi expulso. Diferente dos outros, ele não foi expulso. Ele continua policial. A milícia funciona mais assim para exterminar. Eles querem manter a paz assim. Não mantém a paz, fechando rua (Entrevistado 22).

Sabemos que o extermínio é crime, mas não é imputado a qualquer sujeito como o Entrevistado 22, acima mencionado, em entrevista sobre a milícia ${ }^{1}$, denuncia: Teve até um desses do exterminio, que ele andou preso; ele é policial, porque teve um inquérito, descobriram que ele estava exterminando. Mas ele não foi expulso (não foi "devidamente" punido?). Ele continua policial (continua exterminando?) e a milícia funciona assim mais para exterminar. Exterminio, policial, milícia são formas enunciadas no interior de um discurso que aponta para ilegalidade cometida pelo policial e, ao mesmo tempo, para a prática criminosa e para o próprio sujeito que fica impune e, ainda, para a especialidade da milícia: exterminar.

Esse discurso está inserido em uma conjuntura sócio-histórica, na qual tornou-se constante tratar a violência policial como legítima, quando autorizada pelo Estado. Tornou-se constante significá-la como legítima para garantir a ordem, a paz e a segurança. Tornou-se constante, para uma parte de nossa sociedade, banalizar o extermínio praticado pela polícia, quando um suposto inimigo está inscrito, supostamente, no lugar social e no espaço ditos de marginalidade, como por exemplo, o morador de/na favela. Por outro lado, ordem, paz, segurança, inimigo, formas materiais submetidas à opacidade da língua e ao seu sistema sempre sujeito a equívocos, têm seus significados deslocados, pois eles reclamam outros sentidos e por isso mesmo podem politicamente se dividir, se contrapor, ressignificar em uma rede de discursividades distintas.

O fragmento acima faz parte de um discurso sobre a milícia que põe em cena a polícia de um outro modo, com outros sentidos, na relação com a milícia. Expliquemos. Em 2006, a denominação milícia começou a circular na mídia para se referir à polícia (policiais junto a outros agentes de segurança pública) ${ }^{2}$ que entrava em áreas de favelas ocupadas por narcotraficantes a fim de "combatê-los". Mas, ao invés de efetuar mandados judiciais, prisões outorgadas, entre outros procedimentos legais, esse combate consistia na expulsão, até a execução sumária, daquele considerado inimigo, naquele determinado espaço, visando, com isso, a instauração de uma espécie de dominio. Depois do combate, a milícia passava a controlar ilegalmente as relações comerciais e sociais dessas áreas, a partir da imposição de um dispositivo normativo regido pelo discurso, até então dito moral, de enfrentamento da criminalidade e de manutenção da ordem, da paz e da segurança. Essa prática criminosa explicita a polícia com outro 
nome. Em outros termos, o discurso sobre a milícia explicita uma prática da polícia, primeiramente, porque a milícia assim como a polícia irrompe do interior de uma mesma instituição do Estado, imaginariamente, representante da Lei. A milícia assim se configura nos limites do sentido de polícia e instala imaginariamente a contraparte da Lei, o crime. A milícia é significada e constituída entre a lei e o crime. Esse é um dos efeitos dos discursos sobre a milícia analisados em nossa pesquisa de doutorado (COSTA, 2011). Eles enunciam essa constituição afetada pela formulação de uma tensão, do embate entre o legítimo, o legal e o ilegal, provocados, sobretudo, pela falta e pela falha do Estado enquanto articulador político-simbólico (ORLANDI, 2001a) na contemporaneidade.

Neste artigo, procuramos apresentar, através de recortes da tese, de que modo a falta e a falha do Estado intervêm no processo de individuação ressaltando que a individuação do sujeito pelo Estado, de acordo com Orlandi (2012), é uma questão política dada a relação do indivíduo com a sociedade. Para isso, observamos a configuração da milícia em relação ao espaço da favela e ao Estado. Ao mesmo tempo, procuramos explicitar algumas discursividades que enunciam o modo pelo qual a milícia é identificada.

\section{Interpelação, Individuação e Identificação}

Em Do sujeito na história e no simbólico, Orlandi (2001a) apresenta dois movimentos que constituem o processo de subjetivação do sujeito: Interpelação e Individu(aliz)ação. A autora explica que o indivíduo é interpelado em sujeito pela ideologia, no simbólico, constituindo assim a forma-sujeito histórica (PÊCHEUX, 1975; ORLANDI, 2001a), enquanto o Estado, "com suas instituições e as relações materializadas pela formação social que lhe corresponde" (p. 106) individua essa forma-sujeito. Orlandi acentua que desse processo resulta um indivíduo responsável e dono de sua vontade, com direitos e deveres. Segundo ela, uma vez individuado, esse indivíduo, ou melhor, esse sujeito individuado estabelece uma relação de identificação com uma ou outra formação discursiva produzindo diferentes efeitos. E assim, nas palavras da autora,

se constitui em uma posição-sujeito na sociedade. E isto deriva de seus modos de individuação pelo Estado (ou pela falha do Estado), pela articulação simbólico-política através das instituições e discursos, daí resultando sua inscrição em uma formação discursiva e sua posição sujeito que se inscreve então na formação social com os sentidos que o identificam em sua posição sujeito na sociedade (ORLANDI, 2012, p. 228).

Em Por uma teoria discursiva da resistência do sujeito, Orlandi (2012) retoma esses pressupostos para fazer avançar teoricamente a reflexão sobre a constituição do sujeito na relação com a resistência pensada discursivamente. Com esse propósito, neste estudo, a autora assinala que o "Estado, em uma sociedade de mercado predominantemente, falha em sua função de articu- 
Zaluar \& Conceição (2007) retornam ao significado etimológico da palavra milícia, que sugere serviço militar (militia, de origem latina: miles quer dizer soldado e itia se refere a estado, condição ou atividade) para expor a maneira como essa denominação é tomada em diferentes países. Comumente ela denomina força militar composta "de cidadãos ou civis que pegam em armas para garantir sua defesa, o cumprimento da lei e o serviço paramilitar em situações de emergência, sem que os integrantes recebam salário ou cumpram função especificada em normas institucionais" (p.90). Deu nome ao exército oficial do Canadá; na Suíça, ao exército oficial de reserva; às tropas de reserva, da Austrália e, também, do Canadá Em países que não têm o que se chamou polícia, milícia dá nome a um policiamento regional. $\mathrm{O}$ modo como as autoras conduzem sua exposição nos dá a impressão de que a ideia de segurança e de defesa estrutura as distintas milícias. Mas o sentido de segurança e defesa é bastante ambíguo. Milícia Talibã é, também, denominação do movimento fundamentalista islâmico, cujo preceito é político-religioso e, como sabemos, sua prática é terrorista. lador simbólico e político. E funciona pela falha. Isto é, a falha do Estado" (p. 229). Para Orlandi, essa falha não diz respeito à falta de interesse, descaso, nem significa que o mercado substitua o Estado. Trata-se de uma falha necessária, estruturante do sistema capitalista contemporâneo. Falha que incide sobre o processo de individuação e, portanto, intervém no processo de identificação. Sobre esse último, Pêcheux (1982) propõe pensar a ideologia como um ritual com falhas. Nesse sentido, a falha é o lugar do possível (ORLANDI, 2012, p. 230), lugar em que a ideologia "se abre em ruptura, onde o sujeito pode irromper com seus outros sentidos e com eles ecoar na história" (idem, ibidem, p. 231), pode então, produzir outros efeitos no processo de identificação.

Em relação às formas ideológicas constitutivas da contemporaneidade, Orlandi (2012, p. 226) apresenta duas hipóteses. Segundo a autora, há

na contemporaneidade, duas formas ideológicas que regem o imaginário citadino: 1 . O mito da completude (a sociedade como um todo organizado e coeso) criando a interpretação da desagregação (aquilo que fica fora dela) e 2. em uma perspectiva neoliberal, o fato de que a reciprocidade, a solidariedade cedem lugar à rivalidade, à competição, à marginalidade.

Por esse viés, podemos situar a milícia primeiro em relação à cidade como constituída especificamente em um espaço: o da favela. Espaço esse segregado. Espaço, cuja ausência do Estado é visível e a arbitrariedade das forças policiais também. Em segundo, no ponto de encontro da falha e da falta no Estado, cujo resultado é o confronto ideológico entre aquilo que é ou não dito como marginal. A reflexão de Orlandi, sobretudo, nos leva a compreender a milícia como uma das formas de relação do Estado (ou a sua falta/falha de/na relação) com os sujeitos históricos sociais. Forma essa que, por sua vez, interfere no modo como os sujeitos individuados identificam a milícia, como ela se constitui a partir de um discurso sobre ela.

\section{Milícia e Estado: Modos de Individuação}

A denominação milícia ${ }^{3}$, na relação com diferentes definições, se inscreve em um processo discursivo desencadeado pela substituição de uma denominação por outra. Seu funcionamento discursivo é permeado de equívocos, é, por isso, colocada o tempo todo em suspenso, em nossa pesquisa (COSTA, 2011). Para tecermos algumas considerações sobre ela, neste momento, trazemos uma definição - como veremos equívoca, sobretudo, em seu modo de denominar - formulada no interior dos estudos sociológicos, na qual a milícia é um grupo armado irregular e se define pelos seguintes eixos:

1. controle de um território e da população que nele habita por parte de um grupo armado irregular; 
2. caráter em alguma medida coativo desse controle dos moradores do território;

3. ânimo de lucro individual como motivação principal dos integrantes desses grupos;

4. discurso de legitimação referido à proteção dos habitantes e à instauração de uma ordem que, como toda ordem, garante certos direitos e exclui outros, mas permite gerar regras e expectativas de normatização da conduta;

5. participação ativa e reconhecida de agentes do estado como integrantes dos grupos (CANO \& IOOT, 2008, p. 59).

Estes eixos, por sua vez, deslocam o sentido de militar de milícia, ao passo que fazem referência a um grupo composto por agentes de segurança do Estado (policiais militares e civis, bombeiros, agentes penitenciários), interessados no controle, na coerção, na extorsão, na instauração de uma ordem e normatização da conduta num determinado espaço, de determinados sujeitos. Esse espaço, referido acima como território, não diz respeito a qualquer espaço. Sabemos que a milícia invade, em sua maioria, favelas dominadas por traficantes, ou seja, enunciar território, para se referir ao espaço visado pela milícia, é trazer para dentro dessa definição a problemática em torno da relação de poder(es) que existe nesse espaço, pois, além de o termo presentificar posições divergentes na forma como a favela se significa nessas condições de produção, ele remete a espaço institucionalizado, que está diretamente ligado ao poder de Estado, faz parte dele. Como nos explica Orlandi (2011a):

Se, de um lado, podemos pensar uma definição jurídica para território - limitação da força imperativa das leis ao território que as promulga - de outro, podemos pensar a definição política: condição da terra que faz parte de um Estado. Mas desde que o poder está em jogo temos a possibilidade de intervenção. Portanto estas definições não são inertes, nem politicamente 'neutras'. Há sempre a necessidade de 'órgãos' competentes, legítimos que exerçam territorialidade (p. 20 - grifos da autora).

E, quando se trata da favela e no que se refere à presença de "órgãos" legítimos, neste espaço, já se delineiam, ao menos, duas problemáticas postas pela questão da territorialidade. Primeiro, porque a favela é dita, em termos jurídicos, como ilegal, uma vez que é resultado de ocupações ilegais, de construções irregulares, definida no Boletim Oficial da Secretaria de Serviços Sociais da Cidade como grupo de habitações "de alta densidade, construído de maneira desordenada com material inadequado, sem serviços públicos e sobre terrenos utilizados de maneira ilegal sem o consentimento do proprietário" (cf. DRUMMOND, 1981, p. 2 tradução nossa). Mesmo que essas áreas tenham sido submetidas 
ao projeto de urbanização, denominadas favela-bairro, elas são consideradas, pelos órgãos públicos, bairros não-oficiais, tendo em vista sua condição fundiária. Muitas daquelas que conseguiram a regularização da propriedade, por outro lado, não se eximiram de sua configuração estereotipada de favela, por outras razões, dentre as quais podemos citar o domínio de narcotraficantes. Há um forte imaginário social, que sustenta a configuração de favela enquanto ilegal desde seu surgimento. Segundo Drummond (idem), essa visão do poder público sobre a favela consiste em isolála, marginalizá-la nas suas diferenças de maneira a denunciar um gueto fora da lei que necessita de ordem.

Para Donzelot (2009, p. 47), o isolamento de uma população pobre, numa parte da cidade, autoriza uma gestão interna desta população por uma administração especial, que se encarrega de conhecer suas necessidades específicas e conter sua expansão - nós diríamos seus excessos? Eis aqui, um segundo momento envolvendo essa problemática da territorialidade. Apoiando-nos na afirmação desse autor e articulando-a com a de Orlandi (2011a) acima mencionada, podemos dizer que o órgão de Estado que se faz presente neste território é a polícia. Mas, qual é a prática da polícia, nesse espaço dito ilegal?

Como também sabemos, a polícia, às vezes, divide espaço com os traficantes de drogas, que, em certa medida, gerenciam a favela e são significados como um poder paralelo - nossa análise esbarra, já adiantamos, num recorrente significante: domínio, que, de certo modo, é significado não só na relação com os limites geográficos, mas com o poder exercido pelos narcotraficantes e, também, pela milícia. Poder esse que, em certas favelas, se sobrepõe ao Estado. Com efeito, já se configuram aí relações de força entre o que é dito legal (a polícia, o Estado) e ilegal (a favela, os traficantes), em nossa sociedade. Há o reconhecimento de que a polícia enquanto representante do Estado é legal, de que os narcotraficantes são criminosos, ilegais e de que a favela, mesmo tendo juridicamente reconhecida sua ocupação, é significada como ilegal, em determinadas condições. Por exemplo, quando ocorre uma incursão da polícia na favela, todos se tornam suspeitos, tomados como supostos "ilegais". Se a polícia age com violência, executa um morador, sua prática é justificada, pois um imaginário, que funciona eficazmente, no Brasil, condena o morador de favela ao lugar de marginalidade. Se a polícia executa traficante, o discurso do Estado é o de que a violência foi legítima. É comum ouvirmos dizeres tais como o de que matar "bandido", "criminoso", "assaltante", "traficante" não é crime. Esse é um discurso recorrente na sociedade brasileira. A violência policial é justificada, nesse discurso, por causa dos sentidos atribuídos à favela e aos seus moradores, apagando suas reais condições de existência. $\mathrm{O}$ que vemos, então, é que a territorialidade exercida pela polícia se sustenta pela/na violência. 
Essas questões ressoam no que permite a formação, a ação da milícia, a nosso ver, seu lugar de policial - agente de segurança do Estado, suposto representante da Lei - disposto num espaço tão já marginalizado como é o da favela. Tanto é assim que algo falha ao caracterizar a milícia, na citação acima, enquanto "grupo armado irregular". Ao se dizer irregular, se apaga, se esquece o ilegal; se enfatiza o armado, mas não o criminoso. No entanto, é esse mesmo dizer que nos permite chegar à possibilidade de enunciar grupo de policiais ilegais, por exemplo. O ilegal tem a ver diretamente com o rompimento do princípio básico do poder legislativo, dizer ilegal é dizer contrário à Lei e, portanto, ao Estado. Irregular, por sua vez, direciona, com contornos menos visíveis e puníveis, os sentidos em movimento na relação com o Estado, com a favela, com o favelado, com a própria milícia. Isso tem consequências na produção de evidências, no jogo de representações sociais, no processo de interpelação e individuação dos sujeitos, em nossa formação social. Visto sob outro prisma, irregular ainda nos leva a refletir se a milícia rompe com o Estado. Neste sentido, a milícia coloca o Estado noutra relação com a territorialidade, com suas instituições e no que diz respeito a ele mesmo em sua função de articulador simbólico-político no processo de individuação dos sujeitos, pois, como reflete Orlandi (2011a):

\begin{abstract}
a forma sujeito histórica - em nosso caso capitalista - é individuada pelo Estado, em sua função simbólico-política - pelas instituições e discursos - e é o indivíduo, assim produzido por esse modo de individuação, que, pelo processo de identificação, vai se inserir/identificar com esta ou aquela formação discursiva, constituindo-se em uma posição-sujeito específica na formação social (p. 11).
\end{abstract}

É o modo de individuação na relação com o processo de identificação que está em jogo, nesse caso. A ideologia é o ritual com falhas e o equívoco na definição de milícia aponta para uma delas.

A existência da milícia põe, assim, em foco uma complexa problemática na relação entre cidade, Estado e sujeitos, pois, a partir do domínio de favelas sustentado por práticas violentas, sobretudo, a do extermínio, de coerção em busca de lucro, um grupo ligado às forças de segurança do Estado - policiais reformados, ou na ativa, oriundos das polícias civil, militar, do corpo de bombeiros, agentes penitenciários - subjuga ilegalmente esses espaços e seus moradores, especificamente, no Rio de Janeiro. Ou seja, a milícia comete crimes, mas ancorada em um discurso moral de enfrentamento da criminalidade - semelhante ao da polícia, que talvez seja ainda mais forte que o lugar de policial -, ela expulsa, extermina traficantes e depois, sob o pretexto de manter os locais "seguros", se impõe na favela intervindo na vida dos moradores: cobra taxas de manutenção da segurança, interfere no transporte alternativo, nos serviços de telefonia e internet, no 
comércio, na compra e venda de gás em busca de lucro, controla a entrada e a saída dos moradores, visitantes dos bairros. E, ainda, pune com o extermínio qualquer um que seja considerado como inimigo, a saber: usuários de drogas, ladrões, opositores, invasores, moradores etc.

Até pouco tempo não havia uma lei que a considerasse em sua instância criminosa. Um projeto de lei, que dá existência jurídica à milícia, ao prescrever os crimes praticados por ela, é formulado em 2008. Entretanto, através de um dispositivo normativo próprio, a milícia, com o argumento de "manter a segurança", instaura uma série de normas que estabelece uma determinada ordem. Esse dispositivo se baseia na prática de violência como método de "proteção" e valida a circulação/imposição dessas outras leis nas áreas dominadas. Os sujeitos que moram ou circulam por elas têm de se submeter às leis dos milicianos. São essas normas que organizam as relações sociais nestes espaços. Derivam da ocupação de uma posição de poder, nesses locais, a formulação e imposição de (novas) leis que regem este espaço e as condições de existência. Por conseguinte, os moradores têm de se submeter às novas regras sob a ameaça de punição.

Com isso, pode-se dizer que a Lei e o Estado falham no processo de individuação do sujeito? Essa hipótese dirige a compreensão dos discursos sobre a milícia, a observação da ligação entre Espaço, Sujeito, Estado e Sociedade, em suas múltiplas formas de significá-la.

$\mathrm{Na}$ "medida em que seus membros são agentes de estado, são a representação da autoridade, ganharia sentido o seu discurso de se opor à criminalidade" (CANO \& IOOT, 2008, p. 67). Esse é um dos efeitos ideológicos produzidos, no imaginário, pelo lugar de policial. É desse lugar, enquanto membro do aparato policial, que se sustenta o discurso moral, que apresenta como defesa a execução sumária. Defesa, proteção, segurança são significantes marcados fortemente pelo equívoco, permeados de ambiguidade e produzem efeitos nesse discurso. Por um lado, tem seus sentidos estabilizados na medida em que naturalizam as ações milicianas: julgar, condenar, punir, executar. Um dos vestígios desse efeito estabilizante é o apoio que a milícia recebeu de autoridades do setor de segurança pública, de alguns governantes e de moradores de algumas favelas. Por outro lado, esses sentidos são deslocados em discursos que relacionam a milícia à insegurança, à arbitrariedade, à extorsão, ao extermínio etc.

Vejamos outro fragmento da entrevista realizada com moradores do Rio de Janeiro, no qual é formulado o apoio à milícia. Observem, no entanto, que esse apoio aparece na formulação de um dizer "citado", de dentro, de lá que é atribuído a outro sujeito, ao morador de uma área miliciada, pelo entrevistado, que, por sua vez, se coloca no lugar de fora. Esse discurso aparece alicerçado na ideia de tranquilidade, liberdade, proteção, segurança que a 
milícia oferece em troca de um valorzinho ao contrário do tráfico de drogas que era horrível. O entrevistador pergunta o que a comunidade está achando da milícia:

E6 ${ }^{4}$ : Eu estive conversando com um morador recentemente, de lá, e ele falou: "Olha, meu irmão, melhorou muito, melhorou muito, entendeu? O pessoal paga um valorzinho lá... melhorou, a gente não tem aquele negócio de ter que chegar tarde ter que ser parado ali pelo traficante, não tem isso mais, os moradores são identificados direitinho, então". O tráfico lá era horrivel, era um tráfico pesado, favela do Barbante em Inhoaíba, hoje não, a milícia dominou os moradores estão tranqüilos. Até perguntei isso recente a um amigo que mora lá, "Como é que está lá aquela região?", "Ih, rapaz, acabou, a milícia dominou tudo, está uma maravilha agora. Não há aquele problema mais de você ficar preocupado, sair com a família, sair com o carro, porque a milícia tomou posse lá e acabou o problema". Então os moradores aceitaram a idéia porque tem mais liberdade para sair, tem mais liberdade de entrar com o carro, por exemplo, você vai entrar com o carro numa comunidade dessas está arriscado você perder o carro.

Para este sujeito, a cobrança de taxa não é problema. O problema é o traficante, é a insegurança, o roubo do carro, a falta de liberdade, o constrangimento. E frente a essa situação, o domínio da milícia é uma maravilha. Neste discurso, domínio pode ser substituído por administração? A administração da milícia é uma maravilha? Desta posição discursiva, parece que o controle exercido pela milícia é significado como segurança. A milícia sabe quem é morador e não o submete ao constrangimento de ser parado ali pelo traficante, pois os moradores são identificados direitinho e estão tranquilos, tem mais liberdade para sair, entrar com o carro.

Em outros discursos, a cobrança da taxa, como veremos mais abaixo, é dita dinheiro exigido com violência, ou seja, esse dizer explicita o gesto com que a taxa é cobrada, é extorsão, um crime, uma violência. Aqui, a forma-material enunciada para se referir a ela é valorzinho, que descarta o sentido de violência e explicita outra relação com a milícia. A taxa é insignificante para este sujeito. Ele não se sente submisso à milícia, mas protegido por ela. De que modo se dá a produção destas evidências para este sujeito? O sujeito deste discurso é interpelado pela prática ideológica da milícia que o faz esquecer a ilegalidade dela e atribuir a ela o status de autoridade em seu grau máximo, o do domínio, aqui o soberano. A milícia tomou posse, ou seja, a chegada da milícia é significada como instauração de uma autoridade num espaço antes ocupado pelo tráfico. Diante do tráfico, compara o sujeito, a "gestão"/o governo da milícia é uma maravilha. Essas discursividades ratificam a eficácia do discurso contra a criminalidade formulado pela milícia.

\footnotetext{
de a Entrevistado e o número subsequente, à ordem em que aparece na entrevista.

4 A letra E correspon-
}

\begin{abstract}
Por outro lado, a prática violenta no momento em que a milícia "entra" no bairro é explicitada. O uso da violência, a demonstração de poder no confronto e a expulsão dos traficantes
\end{abstract}


garantem aos milicianos temor de um lado e respeito da comunidade, de outro. A milícia se impõe.

E6: Houve confronto com os traficantes, dominaram mesmo algumas áreas, a milícia dominou. Aqui o Parque Jardim Bangu, traficante não se cria ali porque a milícia se instalou e acabou.

Esse dizer, que incide em dominar, explicita que a autoridade exercida pela milícia é instaurada pelo combate seguido de vitória frente aos traficantes, enquanto a milícia dominou, se instalou e acabou se inscreve numa rede de sentidos que coloca a milícia como força maior, poder absoluto. Desnecessário dizer mais. Pois ela é capaz de pôr um ponto final, mortal no tráfico de drogas. Afinal, traficante não se cria ali: não mora, não domina, não vive... É pela violência que a milícia se impõe.

Atualmente, acumulam-se, no Disque-Denúncia do Rio, milhares de denúncias de extorsão, homicídio, tortura, tráfico de drogas, corrupção, entre outros crimes cometidos pelas milícias. São sintomas de que são muitos os sujeitos que significam a milícia como criminosa. Com efeito, essas denúncias nos apontam outras questões referentes ao significado, novamente ligadas ao papel de policial em nossa sociedade, considerado defensor enquanto parte da instituição policial e quando se integra à milícia pode constituir-se como criminoso, pode ser dito fora da Lei?

Sobre a polícia são evocados diferentes sentidos na constituição de discursos que circulam na conjuntura atual sobre a milícia. Esses sentidos são convocados pela memória discursiva a confrontar-se na história de modo ressignificado, disperso, atravessado com outros dizeres que imputam à polícia outras imagens, especialmente, se projetadas a partir de sua relação com a milícia. Uma delas é explicitada na denúncia de engajamento de policiais em ilegalidades, descrita por Philip Alston ${ }^{5}$, relator da ONU. Ele afirma que as

polícias estaduais, especialmente a polícia militar do Estado, trabalha rotineiramente em outro emprego, quando estão de folga. Alguns formam 'milícias', 'grupos de extermínio', ou 'esquadrões da morte' e outros grupos que agem com violência inclusive execuções extrajudiciais, que ocorrem por vários motivos. Primeiro, procuram dar 'proteção' a comerciantes, fornecedores de transporte alternativo, em que outros são forçados a pagar para este grupo. Dinheiro exigido com violência. Segundo, para evitar facções saiam de seu controle. Pessoas suspeitas de fornecer informações ou colaborar com outras facções são mortas. Em terceiro lugar, apesar de

Relatório da Sociedade Civil para o Relator da Especial da ONU para Execuções, sumárias e extrajudiciais. Rio de Janeiro, 2007. alguns não serem criados como grupos de extermínio de fato, os relacionamentos ilícitos que eles desenvolvem com outros elementos mais poderosos e afluentes da comunidade, resulta freqüentemente no engajamento de assassinatos de aluguel (ALSTON, 2007 apud RIBEIRO, 2008, p. 14 - grifos nossos). 
É interessante e importante ressaltar que, neste discurso, como em muitos outros, a discussão na busca de se definir, de se delimitar o papel da milícia ignora a condição de existência do sujeito submetido ao seu domínio. Um vestígio desse esquecimento pode ser explicitado, por exemplo, no momento em que ao se referir ao sujeito que é forçado a pagar, se enuncia outros: em que outros são forçados a pagar para este grupo. Dinheiro exigido com violência. Há marcada na formulação uma indeterminação do sujeito que ressoa no discurso seu apagamento. Em contrapartida, na mesma formulação, a prática de exigir dinheiro enfatiza a violência. Como dissemos anteriormente, aqui a taxa exigida pela milícia é discursivizada como violência. Ao contrário, de valorzinho, que mostramos em um dos fragmentos anteriores. O processo de produção de evidências desses dois discursos, portanto, percorre direções de sentido diferentes. Ainda em relação ao discurso de Philip Alston, é importante dizer que seu discurso indistingue polícia de milícia. Nesse caso, a denominação nomeia outro ofício, como se milícias, grupos de extermínio ou esquadrões da morte, entre outros, fossem ramos de atuação da polícia. Esse efeito é produzido pelo dizer outro emprego. Milícia aparece então significada como um ramo de atividade paralelo da polícia, cuja principal atividade é a execução. Esse dizer marca outra face da polícia. Por conseguinte, é possível visualizar duas posições discursivas antagônicas sobre a polícia, que, no entanto se recobrem. No caso daquele sujeito que a apoia, ela é interpretada como protetora. Para outros, como criminosa.

\section{O Espaço Simbólico-Político da Favela}

O "modo como se dispõe o espaço é uma maneira de configurar sujeitos em suas relações, de significá-los" (ORLANDI, 2011b, p. 01). Um exemplo: o policial na favela, como é identificado pelo sujeito morador, deste lugar social, neste espaço? Em outra instância, inúmeras vezes o sujeito que mora na favela, o favela(do) é tomado, é significado por esse espaço e vice-versa. Ao longo de

6 A autora analisa um poema postado por um sujeito navegador situado no Complexo da Maré, no Rio de Janeiro, cujo discurso produz efeitos de ruptura e deslizamento dos estabilizados, construindo um lugar de resistência, pautado no "não" de desacordo frente ao "não" do Estado, o "não" maior da morte. Texto apresentado na II Jornada e-Urbano - Cidade e Tecnologia digital: modos de significação do espaço, realizada no dia 28 de junho de 2011, no auditório do IEL/ UNICAMP, gentilmente cedido pela autora. muitos anos o processo de criminalização da favela recai sobre seus habitantes marginalizando-os. Efeito da segregação.

Romão (2011) sublinha algumas negativas historicamente constituídas que recaem sobre a favela, sobre o favelado. Descrevendo a favela como "lugar de direitos negados", a autora enfatiza que a nomeação favelado-bandido é legitimada por uma voz exterior à favela, que impõe o não "à vida como imperativa e como única via possível" ${ }^{\prime \prime}$. Esse modo de significar a favela está relacionado à constituição da milícia face ao Estado, pois o não imposto à favela está ligado à ausência do Estado, de instituições públicas, de acesso aos serviços públicos etc. É importante frisar que a (falta de) segurança aparece entre essas faltas, pois a ideia de espaço perigoso circula desde o surgimento das favelas cariocas, significando-as. Com efeito, a polícia é chamada para intervir, cuja prática, desde então, é violenta. 
Dito de outra maneira, a favela se constitui como espaço na falta do Estado. Um espaço marcado pela falta do Estado, metaforizada na falta de recursos, na falta de infraestrutura, de regularização, etc. Um espaço cujos lugares deixados vazios vão sendo ocupados de diferentes formas.

Valladares (2005) assinala que aos morros, que inicialmente foram ocupados por ex-combatentes da guerra de Canudos, foram destinados imaginariamente os pobres, negros, desempregados, imigrantes. Com isso, as favelas passaram a ser vistas como o espaço dos excluídos. O preconceito que recaía sobre esses sujeitos expandiu-se e se sedimentou na favela. O que, por sua vez, contribuiu rapidamente para a construção da favela como lugar de marginalidade. Os sujeitos foram afetados pelos sentidos desse espaço. Esse processo, no qual percebemos um efeito de metonimização que nos remete à afirmação de que o "desempregado, o desvalido sem domicílio, o inativo sem utilidade, o exilado sem pátria, o prisioneiro a quem se nega o nome ao se chamar por uma matrícula, o imigrante sem direito... são todos definidos por uma falta" (SCHALLER, 2002, p. 151). No tocante ao morador da favela, a falta é sobredeterminada por sua relação com o espaço, na construção estereotipada de seu lugar. Os favelados tornam-se favelados pela ocupação ilegal de uma propriedade, ditos a partir de então como: subversivos, marginais, promíscuos, doentes, preguiçosos, vagabundos, perigosos, desordeiros, imorais. Assim são historicamente significados como "favelados, fora da lei sobre um terreno que não lhes pertence" (DRUMMOND, 1981, p. 1) até chegarem a ter visibilidade a partir de interesses políticos, como eleitores e, em 1950, através de um recenseamento realizado pelo governo, deslocados minimamente para a posição de trabalhadores.

De acordo com Medeiros, o lugar de inscrição do morador de favela configura-se, na atual conjuntura, como um lugar "fora-dentro: fora dos direitos, mas neles incluído pelas penalizações. É esta a sua posição-sujeito na formação discursiva que faz significar cidadão em nossa formação social" (2011, p. 2127).

Em resumo, o que queremos ressaltar é que a configuração da favela como um espaço à margem, segregado, criminalizado recai sobre o sujeito-morador identificando-o, por exemplo, nesta posição-sujeito fora-dentro no interior de nossa formação social. Por conseguinte, tanto a configuração desse espaço como um espaço de faltas quanto a inscrição de seus moradores nessa determinada posição discursiva fora-dentro resultam da individuação pelo Estado, de seu papel como articulador político-simbólico que

Nesse trabalho, Medeiros mostra que o movimento social Posso me identificar se configura como um movimento de resistência a tal inscrição. ora falta, ora falha. Nessa direção, a falha permite a corrupção e violência policial, a instalação do narcotráfico enquanto a falta do Estado e suas instituições deixa um lugar vazio.

A narrativa seguinte trata da descrição de um homem de proezas, valente, de grande coração e nos mostra uma versão de 
como a instalação de um domínio teria ocupado o vazio provocado pela ausência do Estado:

Um dia chegou à favela um homem - Zé da Barra. Vinha do Piraí. Já trazia grande fama. Suas proezas eram conhecidas. Era um valente, mas um grande coração. E Zé da Barra chegou e dominou a favela [...] E a favela que não conhece polícia, não conhece impostos, não conhece autoridades, conheceu Zé da Barra e a ele teve que obedecer. E Zé da Barra ficou sendo o chefe incontestável da Favela (COSTALLAT, 1995, p. 37 apud VALLADARES, 2005, p. 34).

Uma falta é preenchida? Um lugar "vazio", sem representante, sem referência é preenchido. De que modo? À favela, que não conhece polícia, não conhece impostos, não conhece autoridades, é imposta um chefe, que a dominou. O léxico, especialmente, autoridades, chefe, dominou, no nível da formulação, que relaciona a favela a um domínio, à ausência de autoridades, a partir de condições de produção determinadas, nos conduz à figura daquele que manda, Zé da Barra. A incidência, do nível interdiscursivo no eixo da formulação, configura um lugar de poder, de mando ocupado por ele.

O lugar de chefe significado como de comando, de domínio, de autoridade produz, por conseguinte, o seu avesso: o lugar do submisso. É o que de certa forma se textualiza em: E a favela que não conhece polícia [...] conheceu Zé da Barra e a ele teve que obedecer.

Desliza dessa narrativa uma série de já-ditos estereotipados: favela não tem lei, não tem Estado, não tem governo, não paga impostos, não tem ordem... Podemos dizer que a figura de Zé da Barra substitui o Estado, nesse espaço, sobretudo, no processo de individuação desse sujeito? Na atual conjuntura é possível supor que Zé da Barra é então substituído pelo narcotraficante, pela polícia, pela milícia?

Um dos entrevistados tem uma resposta possível:

E30: Assim, eu moro lá desde que eu nasci, e assim desde que eu me conheço por gente tem esse chefão que éo $[Z e ́ X]^{8}$ que manda em tudo lá, que comanda, não deixa entrar tráfico, não deixa bandido roubar, se alguém roubar ele corre atrás. E ele tem todo um, como é que se diz? Um grupo, né? De policiais, que são policiais, mas trabalham pra ele, entendeu? Assim, eu acho, na minha opinião, que foi um tipo de dominação meio que carismática. Esse [Zé X] ele é um ex-policial e acabou... assim... aquele negócio... [...] Ele é tipo assim um líder que no carisma começou a mandar, entendeu? [...] Carisma e poder.

Contrapondo o discurso sobre Zé da Barra com esse sobre Zé X, podemos dizer que Zé da Barra é substituído por Zé X. Ele faz a segurança: não deixa entrar tráfico, não deixa bandido roubar e se alguém roubar ele corre atrás. Ele substitui a polícia, aliás, ele é ex-policial e tem em torno dele uma organização, um grupo de policiais, mas exerce seu papel conforme o seu próprio comando,

8 O nome mencionado na entrevista foi alterado. afinal é ele que manda em tudo lá, ou seja, ele já se coloca como aquele que não segue regras vindas da corporação. 
Observem como é forte o lugar de (ex)policial no dizer: eleé ex-policial e acabou... assim... aquele negócio. Este sujeito parece enunciar que Zé $X$ pôs fim à criminalidade. Se alguém roubar ele corre atrás é modo de não dizer o que se faz com aquele que rouba: bate, expulsa, mata, ou, ainda, um modo de enunciar que $\mathrm{o}$ assaltante não fica impune. Zé $X$ pôs fim à impunidade. $\mathrm{O}$ sujeito que enuncia esquece que Zé $X$ é ex, que ele ocupa um lugar ilegalmente. Os policiais, por sua vez, trabalham para ele e não para o Estado. Aqui o verbo entendeu parece frisar e, ao mesmo tempo, confidenciar o poder de Zé $\mathrm{X}$ em relação a esses policiais. Contraditoriamente, aqui parece lembrar que os policiais se submetem ao poder dele, ilegalmente. Ele é a autoridade, chefão, tipo assim um líder. Vejam que duas discursividades se articulam neste discurso. Dizer chefão é enunciar o poder, o autoritarismo que configuram a imagem de Zé $X$, ao passo que descrevê-lo como tipo assim um líder que exerce um tipo de dominação meio que carismática - e notem que o termo aqui não é domínio, nem comando -, no qual também se define que a dominação é meio que carismática é (d)enunciar, talvez, a estratégia que o leva a constituir-se no lugar do Estado. O sujeito entrevistado conclui: carisma e poder. Duas características, ou melhor, dois sentidos que funcionam articulados no processo de individuação desse sujeito, pois elas fazem parte da imagem construída de Zé $X$, que não é líder religioso, não é líder comunitário, nem líder político, é um líder, cuja constituição se dá numa indefinição entre o autoritarismo e, diferente de Zé da Barra, o carisma. Que sentido tem carisma em tais condições discursivas? Poder e carisma conferem a ele, legitimidade.

Assim como nesse discurso, observamos, ao longo de nossa pesquisa, os processos discursivos desencadeados por formas de significar, modos de individuação instituídos na relação com o espaço político-simbólico, os quais se desenvolvem na falha/ falta do Estado.

\section{Algumas Considerações}

E1: Dois milhões e meio de pessoas, são vidas. Sem governos, sem governo, sem estado. Então, quer dizer, dois milhões e meio de pessoas sem governo, você está me entendo? Sem estado. Estado pratica violência duas vezes, pela ausência dele e quando ele entra na comunidade.

Esse enunciado de base situa as condições de produção de significação que circunscrevem o acontecimento discursivo da milícia: muitas vidas expostas à violência, à dupla violência pela presença e ausência do Estado, sujeitos sem direitos (sem governo, sem estado) num espaço de negações (sem governo, sem estado). Segregados. É diante desse sujeito, nesse espaço, que a milícia se impõe, à sombra do Estado, pois ele falta/falha, na maneira como está investido no modo de existência da prática de milícia e de existência desses dois milhões e meio de pessoas. São condições 
de produção que atravessam, constituem discursos de fora e de dentro das áreas miliciadas à medida que engendram efeitos de evidência.

Ocorre que um significante, recorrentemente, enunciado para significar milícia, contribui, especialmente, para a compreensão de sua prática, em seu acontecimento discursivo. Por isso, voltamo-nos para ele. Trata-se de domínio (dominar, dominada, dominou, dominação), investido e revestido de poder.

Observamos que diferentemente de controle atribuído à polícia, de comando dito para o narcotráfico, a milícia é interpretada, identificada como domínio. Domínio dá sentido à milícia, a partir de duas instâncias: domínio imposto, forçado, violento, sem possibilidade de oposição, cuja significação é determinada por uma formação discursiva opressora, permeada de indeterminações, de indistinções, de silêncio, produzida pela falha do Estado; e domínio instaurado como autoridade, gestor, poder, cujo lugar, tendo ao lado o sentido de controle inscrito numa formação discursiva administrativa, se configura na falta do Estado.

Falha e falta do Estado, em seu papel de articulador político-simbólico, ambas, em constante movimento, são determinantes para a compreensão do modo como se configura a milícia no discurso sobre ela, sobretudo, na tensão que se instala entre o estatuto de legal e de legítimo. Com efeito, onde o Estado falta, o princípio de legitimidade é evocado e sustentado pela ideia de defesa, de segurança.

Face à falha, as práticas de violência, sobretudo, de invasão, de violação de direitos, de estupro, de extorsão e de extermínio significam a milícia, em sua ilegalidade como criminosa. Por conseguinte, explicitam a sua constituição ilegal e a impunidade policial. A polícia em seu grau máximo de violência, "invisível" dado seu lugar de policial, cuja violência se naturalizou, em certa medida. Da falha do Estado resulta a milícia como desdobramento da polícia.

Visto do lugar de policial, de certa forma, a autoridade, conferida à polícia pelo Estado, reveste a milícia de legitimidade e institui outro significado para sua prática. Na base desse processo, está a oferta de segurança. Um dos entrevistados diz que sua comunidade apoia a milícia, a partir do reconhecimento desse lugar de policial:

E5: Apoio. Apoio, apoio total. Aplauso mesmo. Porque agora a gente sabe que não tem marginal, não tem ninguém cheirando por aí, porque parou, tiroteio não tem mais, é muito raro a gente ouvir um tiro e porque são policiais, então são pessoas que vão oferecer segurança pra gente.

Esses deslocamentos, de um lugar para outro, de um lugar permeado por outro, em conflito com outro, provocam o deslizamento dos sentidos. Dispersão. O que nos mostra o discursos sobre 
é uma complexa rede de relações, de significações, posta em movimento pela milícia, que se (nos) situa face ao social, que intervém nas condições reais de existência, ou seja, nos coloca face ao real.

Podemos dizer que legitimidade, legalidade e ilegalidade estão em movimento e funcionam a partir de certos lugares na sociedade. Esse movimento transita por outros discursos, deslocando os sentidos de um lugar para outro. E, se quem decide os sentidos é o político (ORLANDI, 2001b, p. 10), o embate entre legitimidade e legalidade também é regido por ele. O político divide, na língua, os sentidos de ordem, paz e segurança e permite que, em determinados discursos, eles sejam significados como desordem, guerra e insegurança.

\begin{abstract}
In this article, we reflected on how the lack and failure of the State intervenes in the process of individuation underscoring that the individuation of the subject by the State, according to Orlandi (2012), is a political issue because of the relationship of the individual with society. For this reason, we observed the configuration of the militia in the space of slum and in relation to the State. At the same time, we explicate some discursivities, which set out the way in which the militia is identified in discourses about it, especially in an interview conducted with residents of Rio de Janeiro.
\end{abstract}

Keywords: Discourse; Militia; Process of Individuation.

\title{
REFERÊNCIAS
}

CANO, Ignacio \& IOOT, Carolina. Seis por meia dúzia? Um estudo exploratório do fenômeno das chamadas 'milícias' no Rio de Janeiro. In: Segurança, tráfico e milícia no Rio de Janeiro/organização Justiça Global. Rio de Janeiro: Fundação Heinrich Böll, 2008, p. 48-103.

COSTA, Greciely Cristina. Discursos sobre a milícia: nomes, vozes e imagens em movimento na produção de sentidos. Tese (Doutorado em Linguística), Instituto de Estudos da Linguagem da UNICAMP, Campinas: 2011.

DONZELOT, Jacques. La ville à trois vitesses et autres essais. Paris: Edition de la Villette, 2009.

DRUMMOND, Didier. Architectes des favelas. Paris: Dunod, 1981.

MEDEIROS, Vanise. "Posso me identificar?": Mídia, Violência e Movimentos Sociais. In: ZANDWAIS, Ana, ROMÃO, Lucília M. 
S. (Orgs.). Leituras do Político. Porto Alegre: Ed. da Universidade Federal do Rio Grande do Sul, 2011. p. 201-219.

ORLANDI, Eni Puccinelli. Discurso e Texto: Formulação e Circulação dos Sentidos. Campinas, SP: Pontes, 2001a.

ORLANDI, Eni Puccinelli. Tralhas e Troços: o flagrante urbano. In: ORLANDI, E. (Org.). Cidade Atravessada: Os Sentidos Públicos no Espaço Urbano. Campinas, SP: Pontes, 2001b. p. 9-24.

Os sentidos de uma estátua: Fernão Dias, individuação e identidade pousoalegrense. In: ORLANDI, Eni (Org.). Discurso, espaço, memória: caminhos da identidade no Sul de Minas. Campinas, SP: Editora RG, 2011a. p. 13-34.

A Casa e a Rua: uma relação política e social. In: Educação e Realidade. Porto Alegre, 2011b.

SP: Pontes, 2012.

Discurso em Análise: Sujeito, Sentido, Ideologia. Campinas,

PÊCHEUX, Michel. Semântica e Discurso: Uma Crítica à Afirmação do Óbvio. Trad. ORLANDI, E. P. [et al.]. Campinas, SP: Editora da UNICAMP, 1988 [1975].

PÊCHEUX, Michel. Ler o arquivo hoje. Trad. Maria das Graças Lopes Morin do Amaral. In: ORLANDI, Eni Puccinelli (Org.) [et al.]. Gestos de leitura: da história no discurso. Campinas, SP: Editora da Unicamp, 1994 [1982]. p. 55-66.

ROMÃO, Lucília Maria Sousa. No fio da língua, sujeitos e sentidos em movimento. Texto cedido pela autora, 2011.

SCHALLER, Jean-Jacques. Construir uma educação renovada. In: Revista Educação e Pesquisa, USP, São Paulo, ano 28, v. 28, n 2, p. 147-164, jul./dez. 2002.

VALLADARES, Licia do Prado. A invenção da favela: do mito de origem a favela.com. Rio de Janeiro: Editora FGV, 2005.

ZALUAR, Alba; CONCEIÇÃO, Isabel Siqueira. Favelas sob o controle das milícias no Rio de Janeiro: que paz? In: São Paulo em Perspectiva, v. 21, n. 2, p. 89-101, jul./dez. 2007. 